\title{
Attitudes of health workers and outpatients' recovery in public hospitals in Calabar Metropolis, Nigeria: an information analysis
}

\author{
A. M. Ogaboh Agba ${ }^{a}{ }^{,}$, Felix E. Ojong ${ }^{a}$, Abayomi I. Akintola ${ }^{a}$, Gbadebo S. Maruf ${ }^{b}$, \\ Hannah T. Udom ${ }^{c}$, \& Essienawan U. Usung ${ }^{\mathrm{a}}$ \\ ${ }^{a}$ Department of Sociology, University of Calabar, Nigeria \\ ${ }^{b}$ Universiti Utara Malaysia, Sintok, Kedah, Malaysia \\ ${ }^{c}$ Department of Social Work, University of Nigeria, Nsukka, Nigeria
}

\begin{abstract}
The study is an information analysis about the assessed awareness of the attitudes of health workers and outpatients' recovery in public hospitals in Nigeria. Specifically, the study examined negligence and aggressive behaviour by health workers on outpatients' recovery in public hospitals. The study was carried out in public hospitals in Calabar Metropolis, Nigeria. The crosssectional design method was adopted to collect empirical data from outpatient in the hospitals for three months. The study adopted the purposive and volunteer sampling techniques in identifying 400 respondents for the study. Data collected were analysed using simple percentages and Chi-squared statistical tools. Results revealed that there is significant relationship between negligence by health workers and outpatients' recovery $\left(\chi^{2}=13.45 \geq 7.815\right)$, health workers' aggression significantly affect outpatients' recovery $\left(\chi^{2}=97.09 \geq 7.815\right)$. Based on these findings, it was recommended among others that management of public hospitals should put on measures to curtail attitudes of negligence by staff towards patients, by installing closed-circuit television (CCTV) cameras specifically along service points. Management of public hospitals should impose stiff and stringent penalties on staff found to be aggressive towards patients.
\end{abstract}

Keywords: Attitude; health workers; outpatient; negligence; aggressive behavior.

\section{Introduction}

The attitude of some health workers to work and services to patients, especially in public hospitals, has become worrisome. Years of this development led to the death of many patients and has put some more into traumatic conditions. The growing culture of medical tourism, especially among the elites in Nigeria and other developing nations is attributed to the negative habits of health workers. Studies have also shown that attitudinal problem exists among health workers including nurses, doctors, pharmacists, medical laboratory technicians and other paramedics and in all levels of care. According to Obinna (2011), there is no exception to this negative attitude, as majority of the health workers are guilty of this trend, even without provocation.

Contrary to the principle of premium-non-nocere (first, do no harm) which is central to the code of conduct for health workers, the display of negative attitudes towards patients should be the least behavioural trait from any health official. Even in the presence of a life-threatening health condition, most health workers are less concerned. Whether it in a case of emergency, routine doctor's appointment, laboratory test, or any other appointment, the negative attitude of some health workers seems to have become a way of life, negating the noble profession of healthcare delivery (Ukwayi, Angioha, \& Aniah, 2019; Angioha, Nwagboso, Ironbar, \& Ishie, 2018; Ukwayi, Angioham\&

\footnotetext{
* Corresponding author.

E-mail address: ogabohagbagroup@yahoo.com (A. M. Ogaboh Agba)
} 
Ojong-Ejoh, 2019; Agba, Nkpoyen, \& Ushie, 2010). The attitudes of health workers, such as aggression, lack of communication, lack of empathy, nonchalance, etc affect patients' choice of healthcare services. According to Miao, Ma and Ma (2011) outpatient services, though represent an entry point for medical services, can directly influence patients' satisfaction. Where patients perceive health services to be unsatisfactory, there is high possibility that they will seek similar services elsewhere. Manaf and Nooi (2009) posit that prompt response of health workers to patients, provision of adequate information to patients, prevention of overcrowding at service points, hygiene level of the health workers, respect to patient as well as general improvement of staff' attitudes towards the health needs of patients are major indicators for health service satisfaction among patients.

Significant number of studies have also been carried out in Nigeria public hospitals and their outcomes revealing. However, there is near absent of empirical research on the effect of health workers' attitude on patient recovery process. This study is therefore set to bridge this knowledge gap by investigating the correlate between attitude of health workers and the recovery of outpatients. Specifically, the study examines the relationship between negligence by health workers and outpatients' recovery; as well as investigate the links between health workers' aggression and outpatients' recovery.

\section{Literature Review}

\subsection{Health workers' negligence and patients' recovery}

Services of a health facility is determined by the attitude of its workers. This is because the expectations of patients from health workers include demonstration of goodwill, empathy and courtesy (Oluyemi, Yinusa, Abdulateef, Atolagbe, Adejoke, Kehinde, Gbenga \& Motolani, 2018; Agba, Akpanudoedehe, \& Ocheni, 2014; Agba, Nkpoyen, \& Ushie, 2010 Akpabio, Angioha, Egwuonwu, Awusa, \& Ndiyo, 2020). However, the nonchalant attitudes of some health workers have caused many scholars to questions if they understand that health business revolves around the patients. Boudreaux, Ary, Mandry and McCabe (2010), Iliyasu, Abubakar, Law and Gajida (2010) observe that the patient is central to the health business whether it involves response to life-saving interventions and emergencies, time spent by outpatients to access treatment or the challenges experienced in getting prescribed drugs. Net, Chompikul and Sermisri (2007) opine that the nonchalant attitudes of health workers could lead to deaths of many outpatients than the diseases or illnesses that actually took them to the hospitals.

There is also increasing concern that the healthcare delivery system is substituting its humanistic touch of care giving to wealth accumulation and material possession. Vinagree and Neves (2008) and Russell (2008) argue that, unlike in the past where individuals chose the path to care-giving as a call to selfless humanistic service, many health workers today are in the vocation for the purpose of wealth accumulation. Thus, they see patients as nuisance, demanding too much; rather than, patients requiring help, care, love and treatment. Perhaps, this is the reason why many deaths are recorded in Nigeria hospitals while outpatients awaits treatment.

One way to justify the conclusion that health workers today are more interested in the financial gains than offering healthcare to patients is the issue of money before treatment template advocated in both public and private hospitals in Nigeria. The inability of patients to pay what is required on arrival at the hospital often lead to abandonment and some die in the process. This includes cases of emergencies, where a patient is brought to the hospital in dire need of medical attention involving gunshot wounds, accident victims, excessive bleeding, etc. Considering the high level of poverty among many Nigerians, it is often not easy to provide the required amount at the point of entry in the hospital. So by the time the family members or guardians are able to gather the required amount for treatment, the patient may have outlived the period for resuscitation. In most cases, the patients die shortly after payment is made by family members. This trend according to Obinna (2011), has been on-going for long, so much that the former Minister of Health, Prof. Babatunde Osotimehin remarked in 2009 that health workers were largely responsible for the death of patients in various hospitals across the country.

Although critics put the blame of health workers' negligence on lack of effective disciplinary body to checkmate and sanction offending health workers, health professionals on the other hand have blamed the inefficiency in the health care system to capital flight, insufficient health workers and overwhelming number of patients. The justification of the negligence and aggression towards patients is often pecked on the overwhelming presence and ratio of patients to 
a health worker. A study by Hall, Horgan, Stein and Roter (2012) showed that a doctor in a public hospital is responsible to over 200 patients and that most of the health facilities are overstretched as a result of the overwhelming crowds that usually seek medical services. Thus, unfavourable working environment is believed to be the catalyst to health workers' nonchalant attitudes towards patients.

It should be noted that a patients' recovery rate is dependent on healthcare service quality. In this regard, the quality of healthcare service is said to be the measure of degree of inconsistency between patients' perception and expectations. Because perception is usually negative among patients, when it becomes positive, then satisfaction is achieved. Consumer dissatisfaction usually occurs when the expectations of the patients are greater than the actual performance of service delivered by the hospital (Shaofeng, 2012). In contrast, patients often relish with high degree of satisfaction when the perception of services received is clearly in excess of the expectations (Sofaer \& Firminger, 2015; Iji, Angioha, \& Okpa, 2019; Ushie, Agba, Olumodeji \& Attah, 2011; Agba, Ushie \& Osuchukwu, 2010; Iji, Ojong \& Angioha, 2018). Assessment of patients' perception of the quality of care and satisfaction with the health services has assumed a more prominent role in the last two decades especially with the advent of consumer movement organizations in developed countries (Coulter, 2016). The quality of care can be evaluated from the perspective of the patient and managers of institutions (Donabedian, 2010; Agba, Angioha, Akpabio, Akintola \& Maruf, 2021). It provides a feedback about services rendered, highlighting areas of strengths as well as deficiencies that need to be improved upon.

The satisfaction patients get in a particular health services is an indispensable determinant of their healing and rehabilitation. Studies on patients' satisfaction with the service delivery started in the 1970s (Yu, Wang, Chen, Zhang, $\mathrm{Yu} \& \mathrm{Gu}, 2015$ ). Findings from early studies showed high level dissatisfaction with doctors than among nurses (Yu, $\mathrm{Li}$, Xue, Wang, Liu, Chen \& Zhang, 2016). According to Yu, et al. (2016), majority of the dissatisfactions was recorded among outpatients, bothering on distance covered to reach the health facility, time spent waiting for consultation, lack of adequate information, etc. The relevance of these studies has been found not to be only beneficial to patients' recovery but also to managers of health care facilities.

\subsection{Health workers' aggression and recovery of outpatients}

The relationship between patients and health workers in the Nigeria health system is that of command and obey. The monopoly of medical knowledge and competence of healing, is exclusive to health workers, and the perceived incompetence of the patients to treat themselves created this unbalanced relationship. From the perspective of patients, the ideal relationship between the health worker and the patient should be symbiotic as that of a buyer and a seller in a business environment; where both exhibit mutual respect for each other, knowing that the success of one depends on the cooperation of the other (Andersen, 2014; Zaroui, Joulei, Dorabi \& Faraouei, 2015; Attah \& Angioha, 2019; Agba, Ushie, \& Osuchukwu, 2010). But in the health care system, patients are seen and regarded as 'beggars' while the health givers are the 'saviours' and 'givers'. Bitzer, Volkmer, Petrucci, Weissenrieder and Dierks (2012) identified the determining factor to this unfavourable relationship to be good health, which the patient seeks to attain at all cost.

Health workers have ultimate control over the decisions and actions of patients with regards to their care and treatment. In the quest to exercise authority, a patient who disagrees with the instruction or disregards the orders of the health worker is labelled a "bad patient", "stubborn", "troublesome", "insubordinate to treatment" or "disobedient patient" (Andersen, 2014). When such a patient is identified, the health workers becomes aggressive toward him/her and often punish him or her by refusing treatment or simply delaying him or her by treating others behind the queue (Jekwes, Abrahams \& Mvo, 2008; Andersen, 2014). The health worker therefore uses aggression as a way of stamping their authority over patients. Verbal abuse is another form of aggression that is often observed among health workers, especially in public hospitals. Patients who are unable to keep appointment dates and time or considered irresponsible by the health workers were often verbally abused. Dapaah (2016) observe that, most health workers usually abuse and blame patients for their health condition.

Cases of physical abuses are also recorded in some hospitals. Perhaps, due to the authoritative nature of health workers, patients who are perceived to be stubborn are usually abused physically to ensure compliance. For instance, Brown (2010) found in a study in the labour ward of a Kenyan hospital that midwives used physical abuse and bizarre 
approaches such as tying non-compliant patients to their beds so they would be still for examination during labour and be delivered of their babies safely. Another negative attitude of health workers that has been observed in public hospitals is poor communication. It is a fact that majority of health workers do not have the requisite communication skills to communicate with patients. Medical doctors, nurses and other paramedics are fond of talking harshly on patients at the least provocation. Majority of the health workers are seen to be always angry and talk to patients angrily, while trying to communicate with them. Jekwes, Abrahams and Mvo (2008) pointed that the harsh words from health workers have more damaging effects on the health of the patients than the diseases or illnesses that brought them to the hospital.

Attitude of discrimination is another negative attitude identified among health workers, predominantly in public hospitals. Attitudes of discrimination among health workers are seen in different forms and scales. One of the obvious forms of discrimination identified among health workers is the discrimination and exclusion of persons with certain types of diseases; for example, people living with HIV/AIDS (PLWHA). Kapologwe, Kabengula and Msuya (2011) observe high level discrimination among HIV/AIDS patients who routinely visit the hospital for medications. Another form of discrimination seen among health workers is the preference for health services to educated and rich patients to the disadvantage of the poor and illiterates. For instance, in a study of a Ghanaian hospital, Andersen (2014) describes the discrimination as "differential treatment". She noted that educated patients were privileged to receive immediate and high quality treatment in the hospital, while the uneducated and poor patients on the other hand often waited in long queues before receiving treatment. These negative attitudes of health workers bothering on discrimination, oppression, verbal and physical abuses, etc have had damaging effects on the recovery process of patients, especially the outpatients.

\section{Methods}

The study was carried out in one of the public hospitals in Calabar Metropolis, Nigeria. This is because of its large staff strength and corresponding number of outpatients who seek treatment daily in the facility. The study adopted a cross sectional design to collect data from outpatient in the hospital. The study adopted purposive and volunteer sampling techniques in identifying respondents for the study. A total of 400 respondents volunteered to participate in the study and were administered 10-items structured questionnaire on a 5-points Likert Scale, in order to elicit comments and opinions leading to the investigation of the relationship between attitudes of health workers and recovery of outpatients. As part of the sampling technique, the researcher employed purposive sampling technique for identification of outpatients. With this sampling technique, questionnaires were administered to outpatients in different departments and units in the hospital.

The rationale for adopting the volunteer sampling techniques was predicated on the nature of the study, which required comments from only outpatients. More so, the questions in the questionnaire were reduced to 10 in order to accommodate the literacy level, time as well as the psychological state of the respondents who are expected to complete the questionnaire. Each questionnaire had section "A" and "B". Section "A" contained the demographic variables of respondents, which include age, sex, marital status, educational attainment, and occupation. Section "B" on the other hand contained the phenomenal questions, prompting to elicit comments on the relationship between attitudes of health workers and the recovery of outpatients. Each question had five options, reading SA (strongly agreed); A (agreed); U (undecided); D (disagree) as well as SA (strongly disagree). Data collected for the study were presented in tables and analysed in percentages. Instrument for data analysis was the Chi Squared statistical tool.

\section{Result and Discussion}

The socio-demographic data of respondents presented in Table 1 disclosed that 65 respondents $(16.25 \%)$ were males while 335 respondents $(73.75 \%)$ were females. Majority of the respondents $(35.50 \%)$ were within the age bracket of 28 to 37 years while the least age bracket was patients between 68 and above. On marital status of the patients, 83 $(20.75 \%), 284(71 \%)$ as well as $32(8.0 \%)$ were the scores for single respondents, married respondents and widowed respondents, respectively. On the occupations of the respondents, 74 (18.50\%), $161(40.25 \%)$ and $129(32.25 \%)$ were the scores for students, civil servants and business owners, respectively. In identifying the educational level of the patients, 16 (4\%), $52(13 \%), 299(74.75 \%)$ and 33 (8.25\%) were the scores for First School Leaving Certificate 
(FSLC) holders, Senior School Certificate Examination (SSCE) holders, graduates and holders of advanced certificates, respectively.

Table 1. Socio-demographic data of outpatients

\begin{tabular}{llll}
\hline Variables & Indicators & Respondents. & \% \\
\hline Sex & Males & 65 & 16.25 \\
Age & Females & 335 & 73.75 \\
& $18-27$ & 40 & 10.0 \\
& $28-37$ & 142 & 35.50 \\
& $38-47$ & 77 & 19.25 \\
Marital & $48-57$ & 91 & 22.75 \\
& $58-67$ & 33 & 8.25 \\
& 68 and above & 17 & 4.25 \\
Occupation & Single & 83 & 20.75 \\
& Married & 284 & 71 \\
& Divorced & 1 & 0.25 \\
& Widowed & 32 & 8.0 \\
Educational & Student & 74 & 18.50 \\
& Civil servant & 161 & 40.25 \\
& Business & 129 & 32.25 \\
& Others & 36 & 9.0 \\
& FSLC & 16 & 4.0 \\
& SSCE & 52 & 13.0 \\
& Graduate & 299 & 74.75 \\
\hline
\end{tabular}

Table 2 investigated the relationship between negligence by health workers and patients' recovery. From the findings, 294 respondents $(73.50 \%)$ reported that health workers often neglect patients in critical conditions. The study also showed that health workers often delay responding to emergencies (73.75\%); it further revealed that health workers show no empathy towards the recovery of patients $(69.75 \%)$. It depicts that health workers discriminates against patients based on their health condition $(81.25 \%)$ and are often not available on duty $(84.25 \%)$.

Table 2. Negligence by health workers and patients' recovery

\begin{tabular}{|c|c|c|c|c|}
\hline $\mathbf{S} / \mathbf{N}$ & Questions & $\mathrm{A}(\%)$ & D (\%) & $\mathrm{U}(\%)$ \\
\hline 1 & $\begin{array}{l}\text { Health workers frequently neglect patients } \\
\text { in critical condition }\end{array}$ & $\begin{array}{c}294 \\
(73.5)\end{array}$ & $\begin{array}{c}104 \\
(26.0)\end{array}$ & $\begin{array}{c}2 \\
(0.5)\end{array}$ \\
\hline 2 & $\begin{array}{l}\text { Health workers often delay responding to } \\
\text { emergencies }\end{array}$ & $\begin{array}{c}295 \\
(73.75)\end{array}$ & $\begin{array}{c}103 \\
(25.75)\end{array}$ & $\begin{array}{c}2 \\
(0.5)\end{array}$ \\
\hline 3 & $\begin{array}{l}\text { Health workers do not show empathy } \\
\text { towards the recovery of patients }\end{array}$ & $\begin{array}{c}279 \\
(69.75)\end{array}$ & $\begin{array}{c}118 \\
(29.05)\end{array}$ & $\begin{array}{c}3 \\
(0.75)\end{array}$ \\
\hline 4 & $\begin{array}{l}\text { Health workers discriminate patients in } \\
\text { pains }\end{array}$ & $\begin{array}{c}325 \\
(81.25)\end{array}$ & $\begin{array}{c}72 \\
(18.0)\end{array}$ & $\begin{array}{c}3 \\
(0.75)\end{array}$ \\
\hline 5 & $\begin{array}{l}\text { Health workers are not dedicated to their } \\
\text { duties with inmates }\end{array}$ & $\begin{array}{c}337 \\
(84.25)\end{array}$ & $\begin{array}{c}60 \\
(15.0)\end{array}$ & $\begin{array}{c}3 \\
(0.75)\end{array}$ \\
\hline
\end{tabular}


Table 3 shows the relationship between health workers' aggression and patients' recovery. From the findings, 270 respondents $(67.50 \%)$ reported that health workers were often hostile towards patients. The study also found that health workers often verbally abused patients $(73.75 \%)$ and often shout at patients in pains $(84.25 \%)$. Investigating whether health workers' aggressive attitudes affect patients' recovery, 379 respondents $(94.75 \%)$ agreed; while 295 respondents $(73.75 \%)$ agreed that health workers' aggressive attitudes has made them to be afraid of seeking healthcare in public hospitals.

Table 3. Health workers' aggression and patients' recovery

\begin{tabular}{|c|c|c|c|c|}
\hline $\mathbf{S} / \mathbf{N}$ & Questions & $\mathbf{A}(\%)$ & $\mathrm{D}(\%)$ & $\mathbf{U}(\%)$ \\
\hline 6 & Health workers are often hostile to patients & $\begin{array}{c}270 \\
(67.50)\end{array}$ & $\begin{array}{c}128 \\
(32.0)\end{array}$ & $\begin{array}{c}2 \\
(0.5)\end{array}$ \\
\hline 7 & Health workers verbally abused patient & $\begin{array}{c}295 \\
(73.75)\end{array}$ & $\begin{array}{c}103 \\
(25.7)\end{array}$ & $\begin{array}{c}2 \\
(0.5)\end{array}$ \\
\hline 8 & Health workers often shout at inmates & $\begin{array}{c}337 \\
(84.25)\end{array}$ & $\begin{array}{c}60 \\
(15.0)\end{array}$ & $\begin{array}{c}3 \\
(0.75)\end{array}$ \\
\hline 9 & $\begin{array}{l}\text { Patients are usually afraid of seeking } \\
\text { treatment due to the aggressive attitude of } \\
\text { health workers }\end{array}$ & $\begin{array}{c}295 \\
(73.75)\end{array}$ & $\begin{array}{c}102 \\
(25.5)\end{array}$ & $\begin{array}{c}3 \\
(0.75)\end{array}$ \\
\hline 10 & $\begin{array}{l}\text { Aggressive attitudes of health workers affect } \\
\text { patients' recovery }\end{array}$ & $\begin{array}{c}379 \\
(94.75)\end{array}$ & $20(5.0)$ & $\begin{array}{c}1 \\
(0.25)\end{array}$ \\
\hline
\end{tabular}

\subsection{Hypothesis one}

There is no significant relationship between negligence by health workers and outpatients' recovery. This hypothesis is tested using responses plotted in Table 2, which measures whether negligence by health workers affect outpatients' recovery. As displayed in Table 4 , since the calculated $X^{2}$ value of 13.45 is $\geq$ the table value of $7.815, H_{0}$ was rejected and $\mathrm{H}_{\mathrm{I}}$ accepted. Meaning there is a significant relationship between negligence by health workers and outpatients' recovery.

Table 4. Chi-square showing negligence by health workers and outpatients recovery

\begin{tabular}{|c|c|c|c|c|c|}
\hline Cell & o & e & $\mathbf{o}-\mathbf{e}$ & $(0-e)^{2}$ & $\frac{(\mathbf{0}-\mathbf{e})^{2}}{\mathrm{e}}$ \\
\hline 1 & 294 & 313.14 & 19.14 & 366.33 & 1.16 \\
\hline 2 & 104 & 104.59 & 0.59 & 0.34 & 0.03 \\
\hline 3 & 298 & 313.14 & 15.14 & 229.21 & 0.73 \\
\hline 4 & 103 & 104.59 & 1.59 & 2.52 & 0.02 \\
\hline 5 & 325 & 312.35 & 12.65 & 160.02 & 0.51 \\
\hline 6 & 72 & 84.64 & 12.64 & 160.25 & 1.89 \\
\hline 7 & 337 & 312.35 & 24.65 & 607.62 & 1.94 \\
\hline 8 & 60 & 84.64 & 24.65 & 607.62 & 7.17 \\
\hline \multicolumn{6}{|c|}{$\begin{array}{c}\sum \mathrm{n}=\underline{(\mathbf{( o - e})^{2}} \\
\mathbf{e}=\mathbf{1 3 . 4 5}\end{array}$} \\
\hline
\end{tabular}




\subsection{Hypothesis two}

Health workers' aggression does not significantly relate to outpatients' recovery. This hypothesis is tested using responses plotted in Table 3 which measures whether health workers' aggression affects patients' recovery. As displayed in Table 5, since the calculated $\mathrm{X}^{2}$ value of 97.09 is $\geq$ the table value of $7.815, \mathrm{H}_{0}$ was rejected and $\mathrm{H}_{\mathrm{I}}$ accepted. This suggests that there is a significant relationship between health workers' aggression and patients' recovery.

Table 5. Chi-square showing health workers' aggression and patients' recovery

\begin{tabular}{cccccc}
\hline Cell & $\mathbf{0}$ & $\mathbf{e}$ & $\mathbf{o}-\mathbf{e}$ & $(\mathbf{o}-\mathbf{e})^{\mathbf{2}}$ & $\frac{(\mathbf{0}-\mathbf{e})^{\mathbf{2}}}{\mathbf{e}}$ \\
\hline 1 & 295 & 309.75 & 14.75 & 217.56 & 0.70 \\
2 & 103 & 88.25 & 14.75 & 217.56 & 2.46 \\
3 & 270 & 309.75 & 39.75 & 1580.06 & 5.10 \\
4 & 128 & 88.25 & 39.75 & 1580.06 & 17.90 \\
5 & 295 & 308.97 & 13.97 & 195.16 & 0.63 \\
6 & 102 & 88.02 & 13.97 & 195.16 & 2.21 \\
7 & 379 & 310.52 & 68.48 & 4689.51 & 15.10 \\
8 & 20 & 88.47 & 68.47 & 4688.14 & 52.99 \\
\hline \multicolumn{5}{c}{$\begin{array}{c}\sum \mathbf{n}=\underline{(\mathbf{0}-\mathbf{e})^{2}} \\
\mathbf{e}=\mathbf{9 7 . 0 9}\end{array}$} \\
\hline
\end{tabular}

\subsection{Discussion of findings}

The findings of this study was quite revealing; it showed that attitude of health workers influences outpatients' recovery in public hospitals in Calabar Metropolis, Nigeria. It showed that negligence by health workers affects the recovery rate of outpatients. Health workers frequently neglect outpatients in critical conditions; they delay responding to emergencies and shows little empathy towards the recovery of patients. They also discriminate against patients based on their socio-economic status. This outcome is in line with the findings of Vinagree and Neves (2008), Russel (2008), Oluyemi, Yinusa, Abdulateef, Atolagbe, Adejoke, Kekinde, Gbenga, and Motolani (2018), who argue that negligence by some health workers accounts for the death of many patients awaiting treatment in public hospitals.

Similarly, Obinna (2011) posit that some health workers are largely responsible for the death of patients in various hospitals across Nigeria. Although this may be true, Hall, Horgan, Stein and Roter (2012) argue that, the negligence by health workers that leads to patients' death are not deliberate, but orchestrated by over-stressed facilities and overcrowding. They posit that, a doctor in public hospital is responsible to over 200 patient as against best practices. Nonchalant attitude of health workers towards outpatient is also attributed to unfavourable working conditions.

The study revealed that health workers' aggressive behaviour affect outpatients recovery in public hospitals. This corroborates with the ideas of Andersen (2014), Zaroui, Joulei, Dorabi and Faraouei (2015), who posit that a situation where health workers regards patients as "beggars" and health givers as "saviour" create aggressive behaviour among health officials, which negatively affect the recovery of outpatients in most hospitals. Andersen (2014) observe that, health workers' aggression towards patient can take the form of refusing or delaying treatment, verbal attack or labelling of patient as "bad patient"; and all these affect the recovery rate of outpatients.

More so, Brown (2010) and Dapaah (2016) posit that some health workers physically abuse patients and blame them for their health conditions rather than provide ways for expediting their recovery. According to Jekwes, Abraham and Mvo (2008), hard worlds from health workers have significant damaging effect on the health of patients than the illnesses that informed their coming to the hospital. 


\section{Conclusion}

This study on the attitudes of health workers and outpatients' recovery was carried out in public hospitals on Calabar Metropolis, Cross River State, Nigeria. The objectives of the study were to identify the relationship between health workers' attitudes such as aggression and negligence on recovery of outpatients in public hospitals. A sampled size of 400 respondents participated in the study. Analysis of information gathered from respondents revealed that there is a significant relationship between negligence by health workers and recovery of outpatients in public hospitals. It also showed that negligence by health workers affects treatment and rehabilitation processes of patients. It reveals a significant relationship between health workers' aggression and recovery of outpatients; which suggests that negative attitudes of health workers such as verbal and physical abuse, excessive authority, discrimination and positioning of blames on patients hinders their treatment and recovery. Based on this finding, the study recommended that: Management of public hospitals should put on measures of curtailing frequent attitudes of negligence by staff towards patients, by installing closed-circuit television (CCTV) cameras specifically along service points. Management of public hospitals should also impose stiff and stringent penalties on staff found to be aggressive towards patients. Again, management of public hospitals should establish reward system for well-behaved staff.

\section{References}

Abiodun, O. (2011). Knowledge and attitude concerning mental health of primary health care workers in Nigeria. International Journal of Social Psychiatry, 37(2), 23-28.

Agba, A. M. O., Ocheni, S. \& Nkpoyen, F. (2014). Microfinance credit scheme and poverty reduction among lowincome workers in Nigeria. Journal of Good Governance and Sustainable Development in Africa, 2(1), 1-16.

Agba, A. M. O., Ushie, E. M., Ushie, M. A., Bassey, A. O. \& Agba, M. S. (2009). Human development trend in Nigeria: The need for concrete implementation of seven the point agenda. Nigerian Journal of Social and Development Issues, 6(1), 15-28.

Agba, A. O., Angioha, P. U., Akpabio, N. G., Akintola, A., \& Maruf, G. S. (2021). Can workplace inducements influence labour turnover? Quantitative Economics and Management Studies, 2(6). https://doi.org/10.35877/454RI.qems306

Agba, A. M. O. Nkpoyen, f. \& Ushie, E. M. (2010),“Career development and employee commitment in industrial organizations in Calabar, Nigeria", American Journal of Scientific and Industrial Research, Vol. 1 Issue 2, pp. 105-114.

Edem, O. E., Agba, A. M. O. \& Ojong, F. E. (2020). Centrifugal Cause of Household Poverty in Nigeria. FWU Journal of Social Sciences, 14 (4), 43-56

Agba, A. M. O., Akpanudoedehe, J. J. \& Ocheni, S. (2014). Financing Poverty Reduction Programmes in Rural Areas of Nigeria: The Role of Non-Governmental Organizations (NGOs). International Journal of Democratic and Development Studies (IJDDS), Vol. 2, No. 1, Pp. 1-16

Akpabio, U. P., Angioha, P. U., Egwuonwu, C. V., Awusa, E. B., \& Ndiyo, M. N. (2020). Risk Factors of Maternal Mortality in Calabar. JINAV: Journal of Information and Visualization, 1(2), 83-92. https://doi.org/10.35877/454RI.jinav262

Angioha, P. U., Nwagboso, S. N., Ironbar, A. E. \& Ishie, E. U. (2018). Underemployment: A Sociological and Policy Analysis of Workers Well-Being in Hospitality Industry in Calabar, Cross River State, Nigeria. IOSR Journal of Humanities and Social Science (IOSR-JHSS), Volume 23, Issue 6, Ver. 5 (June. 2018) PP 57-66.

Ukwayi, J. K., Angioha, P. U. \& Aniah, E. A. (2019). Associate Factor of Trafficking in Women and Children in Calabar, Cross River State, Nigeria. European Journal of Political Science Studies 3 (1), 1-15

Andersen, H. (2014). Villagers: Differential treatment in a Ghanaian hospital. Social Science and Medicine, 59(10), 2003-2012. 
Attah, F. M \& Angioha, P. U (2019). Examining the level of relationship between working condition predictor variables: Remuneration, working hours, office design, job security and workers wellbeing and productivity in commercial banks. International Journal of Scientific and Research Publications (IJSRP), 9(5), DOI: http://dx.doi.org/10.29322/IJSRP.9.05.2019.p896.

Bitzer, E., Volkmer, S., Petrucci, M., Weissenrieder, N. \& Dierks, M. (2012). Patient satisfaction in paediatric outpatient settings from the parents' perspective-the child ZAP: a psychometrically validated standardized questionnaire. BMC Health Service Research, 12(1), 347-52.

Boudreaux, E., Ary, R., Mandry, C. \& McCabe, B. (2010). Determinants of patient satisfaction in a large, municipal ED: the role of demographic variables, visit characteristics, and patient perceptions. American Journal of Emerging Medicine, 18(4), 394 - 400.

Brown, H. (2010). If we sympathise with them they'll relax: fear/respect and medical care in a Kenyan hospital. Medische Antropologie, 22(1), 125-142.

Coulter, A. (2016). Can patient assess the quality of health care? BMJ., 333(7557), 1-2.

Donabedian, A. (2010). Exploration in quality assessment and monitoring: The definition of quality and approaches to its assessment. Ann Arbor MI Health Administration Press, 21(1), 14-19.

Hall, J., Horgan, T., Stein, T. \& Roter, D. (2012). Liking in the physician-patient relationship. Patient Education and Counselling, 48(1), 69-77.

Ibrahim, L., Hadijia, I.S., Nguku, P., \& Nsubuga, P. (2014). Health care workers' knowledge and attitude towards TB patients under Direct Observation of Treatment in Plateau State Nigeria, 2011. Pan African Medical Journal. $18(8)$.

Iji, M. E, Angioha P. U. \& Okpa, J. T. (2019). Working hours and job security: An analysis of their relationship with commercial bank workers well-being and performance in Cross River State, Nigeria. European Journal of Economic and Financial Research, 3(4).

Iji, M. E., Ojong, F. \& Angioha, P. U. (2018). Microfinance credit programmes: Implications on poverty reduction in Southern Senatorial District of Cross River State, Nigeria. IOSR Journal of Humanities and Social Science (IOSR-JHSS), 23(6), 38-45.

Iliyasu, Z., Abubakar, I., Abubakar, S., Lawan, U. \& Gajida, A. (2010). Patients' satisfaction with services obtained from Aminu Kano teaching hospital, Kano, Northern Nigeria. Niger Journal of Clinical Practice, 13(1), 371-8.

Inyang, M. \& Doubrapade, W. (2016). The inextricable effect of health worker's attitude on primary health care implementation in South-South, Nigeria. Journal of Public Health Research. 6(2), 38-44.

Jewkes, R., Abrahams, N. \& Mvo, Z. (2008). Why do nurses abuse patients? Reflections from South African obstetric services. Journal of Social Science and Medicine, 47(11), 1781-1795.

Kapologwe, N., Kabengula, J. \& Msuya, S. (2011). Perceived barriers and attitudes of health care providers towards Provider-Initiated HIV Testing and Counseling in Mbeya region, Southern Highland Zone of Tanzania. The Pan African Medical Journal, 8(17).

Manaf, N. \& Nooi, P. (2009). Patient satisfaction as an indicator of service quality in Malaysian public hospitals. Asian Journal on Quality, 10(1), 77-87.

Miao, F., Ma, Z. \& Ma, X. (2011). The importance of hospital quality management of outpatient services. Chinese Journal of Modern Hospital Management, 9(5), 71-72.

Net, N., Chompikul, J. \& Sermisri, S. (2007). Patient satisfaction with health services in the Outpatient Department Clinic of Nangmamyen Community Hospital, Sakeao Province, Thailand. Journal of Public Health and Development, 5(2), 33-42. 
Obinna, C. (2011). How poor attitude of health workers is killing healthcare delivery in Nigeria. Obtained from: https://www.vanguardngr.com/2011/09/how-poor-attitude-of-health-workers-is-killing-healthcare-deliveryin-nigeria. Vanguard Newspaper September $6^{\text {th }} 2011$.

Ogaboh, A. A. M., Ushie, E. M., \& Osuchukwu, N. C. (2010). National Health Insurance Scheme (NHIS) and employees' access to healthcare services in Cross Rivers state, Nigeria. Global Journal of Human Social Science, 10(7), 9- 15.

Ojong-Ejoh, M. U., Angioha, P. U., Agba, R. U., Aniah, E. A., Salimon, M. G., \& Akintola, A. (2021). Operating SMEs in the Face of the Covid-19 Pandemic in Calabar. Quantitative Economics and Management Studies, 2(5), 272-280. https://doi.org/10.35877/454RI.qems305

Olowookere, S., Abioye-Kuteyi, E., Adepoju, O., Esan, O., Adeolu, T., Adeoye, T., Adepoju, A. \& Aderogba, A. (2015). Knowledge, attitude and practice of health workers in a tertiary hospital in Ile-Ife, Nigeria: Towards Ebola virus disease. Journal of Tropical Medicine, 38(6), 44-51.

Oluyemi, J., Yinusa, M., Abdulateef, R., Atolagbe, E., Adejoke, J., Kehinde, K., Gbenga, P. \& Motolani, W. (2018). Attitudes of health workers towards patients: an aftermath of Ebola outbreak in Nigeria. Sierra Leone Journal of Biomedical Research, 9(2), 47-53.

Russell, S. (2008). Demand-side factors affecting health seeking behaviour in Ghana. GU Journal of Health Services, $5(1), 1-14$.

Shaofeng, L. (2012). Implementation and effective evaluation of the performance in the high-quality nursing service. Today Nurse, 12(1), 190-195.

Sofaer, S. \& Firminger, K. (2015). Patient perception of the quality of health services. Annual Review of Public Health, 26(1), 513-59.

Ushie, E. M., Agba, A. M. O., Agba, M. S. \& Best, E. (2010). Supplementary livelihood strategies among workers in Nigeria: Implications for organizational growth and effectiveness. International Journal of Business and Management (CCSE), 5(3), 146-154.

Ushie, M. A., Agba A. M.O, Olumodeji, E. O. \& Attah, F. (2011) Socio-cultural and economic determinants of fertility differentials in rural and urban Cross Rivers State, Nigeria, Journal of Geography and Regional Planning, 4(7), 383-391.

Vinagree, M. H. \& Neves, J. (2008). The influence of service quality and patients emotion on satisfaction. International Journal of Health Care Quality Assurance, 21(1), 87-103.

Yu, Q., Wang, X., Chen, Y., Zhang, S., Yu, C. \& Gu, Y. (2015). Studying on the progress of research in patients' satisfaction on medical services and its problems. Chinese Health Services Management, 32(2), 105-107.

Yu, W., Li, M., Xue, C., Wang, J., Liu, J., Chen, H. \& Zhang, L. (2016). Determinants and influencing mechanism of outpatient satisfaction: a survey on tertiary hospitals in the People's Republic of China. Journal of Patient Preference and Adherence, 10(1), 601-612.

Zaroui, N., Joulei, H., Dorabi, E. \& Faraouei, M. (2015). Stigmatize attitude of healthcare providers: a barrier for delivery of health services to HIV positive patients. International Journal of Community Based Nursing and Midwifery, 3(4), 292-300.

Ukwayi, J. K., Angioha, P. U. \& Ojong-Ejoh, M. U. (2018). Youth empowerment: A criminological approach for crime prevention and control in Cross River State, Nigeria. IOSR Journal of Humanities and Social Science (IOSR-JHSS), 22 (11), 73-81. 